\title{
ДОСЛІДЖЕННЯ УКРАЇНСЬКО-НІМЕЦЬКИХ ЛЕКСИЧНИХ ПАРАЛЕЛЕЙ У СЛОВНИКОВОМУ ФОРМАТІ
}

\author{
ВОЛОДИМИР ДУБІЧИНСЬКИЙ \\ Варшавський університет, Варшава - Польща \\ v.dubichynskyi@uw.edu.pl; ORCID: 0000-0001-8115-7015
}

ТІЛЬМАНН РОЙТЕР

Альпен-Адріа університет, Клагенфурт - Австрія tilmann.reuther@aau.at; ORCID: 0000-0002-4475-9014

\section{BADANIE UKRAIŃSKO-NIEMIECKICH PARALELI LEKSYKALNYCH W FORMACIE SŁOWNIKOWYM}

WOEODYMYR DUBICZYNSKI

Uniwersytet Warszawski, Warszawa — Polska

TILMANN REUTHER

Uniwersytet Alpejsko-Adriatycki, Klagenfurt — Austria

STRESZCZENIE. Artykuł dotyczy kwestii opisu leksykograficznego ukraińskoniemieckich paraleli leksykalnych, których cechą charakterystyczną jest podobieństwo pod względem brzmienia i pisowni oraz niezupełne podobieństwo bądź jego brak pod względem znaczenia. Przytoczono przykłady opisu słownikowego homonimów i paronimów międzyjęzykowych.

Słowa kluczowe: leksykografia, paralele leksykalne, homonimy międzyjęzykowe, paronimy międzyjęzykowe.

\section{THE STUDY OF UKRAINIAN AND GERMAN LEXICAL PARALLELS IN DICTIONARY FORMAT \\ VOLODYMYR DUBICHYNSKYI \\ Warsaw University, Warsaw — Poland \\ TILMANN REUTHER \\ Alpen-Adria Universität, Klagenfurt - Austria}

ABSTRACT. The article presents the lexicographical description of lexical parallels formally similar words in two languages which are semantically similar or not - for Contemporary Ukrainian and German. In addition, the authors revise the concepts of crosslinguistic homonyms and synonyms. paronyms.

Key words: lexicography, lexical parallels, crosslinguistic homonyms, crosslinguistic

сучасному перекладознавстві актуальними є дослідження спільного та відмінного в порівнюваних мовах, явища інтерференційного характеру, національно-культурні особливості семантики лексичних одиниць і пошуки адекватних перекладних еквівалентів у мовах оригіналу та перекладу. 
Цікавим для контрастивної лінгвістики залишається лексикографічний опис так званих “хибних друзів перекладача", чи міжмовних омонімів / паронімів двох порівнюваних мов. Безпосереднім результатом такого опису можна вважати низку словників, що вийшли в XX-XXI століттях ${ }^{1}$.

Виходячи 3 теорії, що розглядається авторами цієї розвідки в попередніх публікація $\mathrm{x}^{2}$, для позначення схожих за зовнішньою формою (за вимовою й написанням) ${ }^{3}$ лексичних одиниць двох синхронічно порівнюваних мов із частковим або повним незбігом / збігом значень пропонуємо термін лексичні naралелі (ЛП), який поєднує такі відомі в сучасній лінгвістиці назви цього лінгвокультурологічного явища, як, напр., паралекси, парасеманти, діалексеми, міжмовні омоніми, хибні еквіваленти, “фальшиві друзі перекладача", псевдоінтерначіоналізми, слова-аналоги, апроксимати, гетероніми, лексичні пастки, тавтоніми тощо.

Методика вивчення лексичних паралелей передбачає на рівні окремих значень слова розглянути національно-культурну своєрідність лексичних одиниць однієї мови порівняно з їхніми корелятами в іншій мові.

За умови інтенсифікації мовних контактів, передусім такої їхньої форми, як обмін різного роду інформацією, науковими, технічними та культурними досягненнями й цінностями народів, установлюється семантична рівновага систем контактувальних мов, формується вирівнювання понятійних планів лексичних одиниць, що спонукає мови до спільних пошуків єдиних, схожих схем і моделей на рівні семантичних структур.

Понятійна еквівалентність слів різних мов у поєднанні з формальною (зовнішньою) схожістю лексичних одиниць, що, власне, і становить сутність

${ }^{1}$ Див., напр.: M. Koessler, J. Derocquigny, Les faux amis ou les pièges du vocabulaire anglais. Conseils aux traducteurs, Paris 1928; I. Kozielew ski, Stownik wyrazów o podobnym brzmieniu a odmiennym znaczeniu w języku rosyjskim i polskim, Warszawa 1959; J. Viček, Uskali ruské slovni zásoby. Slovnik rusko-české homonymie a paronymie, Praha 1966; В. В. Акуленко, С. Ю. Комиссарчик, Р. В. Погорелова, В. Л. Юхт, Англо-русский и русскоанглийский словарь “ложных друзей переводчика", гл. ред. В. В. Акуленко, Москва 1969; К.-Г. М. Готлиб, Немечко-русский и русско-немечкий словарь "ложных друзей переводчика”, Москва 1972; В. Л. Муравьев, “Ложные друзья переводчика”, пособие для учителя франиузского языка, Москва 1985; M. Szałek, J. Nečas, Czesko-polska homonimia, Poznań 1993; M. Karpaczewa, Ch. Syme on owa, E. Tokarz, Pułapki leksykalne: Stownik aproksymatów polsko-butgarskich, Katowice 1994; R. Lipczuk, A. Kątny, Ch. Schatte, Niemiecko-polski stownik tautonimów, Warszawa 1995; М. П. Кочерган, Словарь русско-украинских межъязыковых омонимов, Киев 1997; Е. Tok arz, Pułapki leksykalne: Stownik aproksymatów polsko-chorwackich, Katowice 1998; U. Borgwardt, H. Walter, Fehler ABC Deutsch-Russisch, Stuttgart 1999; D. Š i k ka, Rečnik srpsko-poljskih homonima i paronima, Poznań 1999; С. И. Канонич, 300 ложных друзей переводчика: Испанско-русский словарь-справочник, Москва 2000; К. Кусаль, Русско-польский словарь межъязыковых омонимов, Вроцлав 2002; M. Szałek, Stownik homonimów rosyjsko-polskich, Poznań 2004; Czesko-polski słownik zdrawliwych wyrazów i pułapek frazeologicznych, pod red. T. Z. Orłoś, wyd. II, Kraków 2006; I. Кон онен но, О. Спів ак, Украӥнсько-польський словник міжмовних омонімів і паронімів, Київ 2008 та ін.

${ }^{2}$ V. Dubichynskyi, T. Reuther, Lexical parallels: definitions, types, examples (Russian, German, English, Spanish), [в:] Cмысль, тексты и другие захватываюшие сюжеты, сб. статей в честь 80-летия И. А. Мельчука, Москва 2012, с. 124-134; В. Дубічи н ський, Т. Ройтер, Теоретичні та практичні засади лексикографічного опису українсько-німецьких лексичних паралелей, [в:] Украйнська і слов'янська тлумачна та перекладна лексикографія, відп. ред. І. С. Гнатюк, Київ 2012, с. 114-119; В. Дубичинский, Т. Ройтер, Теория и лексикографическое описание лексических параллелей, моногр., Харьков 2015.

${ }^{3}$ Докладніше про особливості схожості зовнішніх форм лексичних одиниць української та німецької мов див.: В. Дубичи н ский, Т. Ройтер, Уточнения к определению лексических параллелей, [в:] „Vocabulum et vocabularium”, Минск 2017, вып. 15, с. 353-358. 
лексичних паралелей, не лише сприяє міжперекладності, але й полегшує взаємну впізнаваність мовних одиниць у контексті, що, відповідно, сприяє комунікації та розвитку перекладацьких тактик.

Зазначимо також, що кожна національна культура має у своєму розпорядженні такий мовний матеріал (і зокрема лексичний склад), який, з одного боку, повинен відображати самопізнання народу (національно-специфічний аспект), а з другого - сприйняття цим народом світових наукових знань, естетичних поглядів тощо (інтернаціональний, загальнолюдський аспекти).

Культурологічна та перекладацька практика, як правило, спонукає робити поправку на національно-історичну систему понять і цінностей різних культур, тобто враховувати, що представник іншого народу може сприймати світ трохи інакше. Саме в національно-культурних особливостях словникового складу тієї чи тієї мови й полягає своєрідність кожної з мов і культур різних народів.

На лексичному рівні національно-культурна специфіка кожної лексичної одиниці виражається, зокрема, усередині окремого значення, і в екстралінгвальних семантичних частках значення, і окремими специфічними значеннями (семемами) слова. Національно-культурні особливості лексичних паралелей можна виявити під час аналізу семантичних структур зовні схожих лексичних одиниць двох і більше синхронічно порівнюваних мов.

3 історичного погляду національно-культурний аспект лексичних паралелей стосується здебільшого німецьких, англійських, польських і російських запозичень в українську мову. Стану вивчення питання ЛП-запозичень із цих мов присвячено три праці останнього часу. Так, Ю. Бестерс-Дільгер ${ }^{4}$ розглядає німецькі запозичення в українській мові на межі XIX-XX ст. до кінця XX ст. (30крема запозичення 3 австрійського варіанта німецької мови) та можливу роль польської мови як мови-посередниці. Стаття містить численні переліки германізмів і їхню оцінку п'ятьма респондентами опитування, проведеного у Львові та Чернівцях, щодо актуальності цих запозичень у сучасній українській мові. Н. Філатова ${ }^{5}$ розглядає політичну лексику $1990-$ х років у чотирьох мовах: українській, російській, німецькій та англійській - i торує шляхи оновлення української лексики за допомогою запозичень 3 англійської та російської мов. Праця демонструє вагомий досвід створення словника політичної термінології. Словник WDLP $^{6} \epsilon$ найбільш повною й авторитетною працею в галузі німецьких запозичень у польській мові із часів середньовіччя до середини $\mathrm{XX}$ століття. У його словникових статтях можна розглянути шляхи запозичень германізмів через польську мову в мову українську.

Дослідження ЛП у лексикографічному форматі втілюється авторами цієї праці в створюваному словнику українсько-німецьких лексичних паралелей, у якому описуються слова української мови активного словникового складу з їхніми німецькими відповідниками.

${ }^{4}$ J. B esters-Dilger, Deutsche lexikalische Entlehnungen im Ukrainischen. Zur Frage der polnischen Vermittlung und heutigen Aktualität, [in:] Litteraria humanitas XI: Crossroads of Cultures: Central Europe, red. I. Pospíšil, Brno 2002, s. 25-51.

${ }_{5}^{5}$ N. Filatova, Ukrainisch im Kontakt mit anderen europäischen Sprachen. Englische, deutsche, russische Entlehnungen im Bereich der Politik, Erlangen 2007.

${ }^{6} \mathrm{~W}$ D L P $=$ Wörterbuch der deutschen Lehnwörter in der polnischen Schrift- und Standardsprache. Von den Anfängendes polnischen Schrifttums bis in die Mitte des 20. Jahrhunderts. Hgg. Andrzej de Vincenz, Gerd Hentsche1. Oldenburg 2010 (=Studia Slavica Oldenburgensia 20), [in:] Elektronische Ressource: http://diglib.bis.uni-oldenburg.de/bis-verlag/wdlp/ab_A.html (20.10.2017). 
Основним принципом відбору була прийнята насамперед навчальнометодична доцільність і контрастивна цінність слова, а також розв'язання перекладацьких труднощів і виявлення нюансів граматичного, стилістичного, територіального та деяких інших характеристик порівнюваних слів.

За принцип розташування значень порівнюваних слів узята актуальність цього значення для сучасної живої мови середнього носія мови. Термінологічні значення, як правило, долучаються після нетермінологічних із урахуванням їхньої поширеності й актуальності. Кожне значення як українського, так і німецького слова оснащується ілюстративними словосполуками задля уточнення семантики та контексту використання тієї чи тієї лексичної одиниці.

Словник містить близько 700 пар хибних, неповних і повних лексичних паралелей.

У випадку незбіжності всіх значень зовнішньо схожих лексичних одиниць двох чи більше синхронічно порівнюваних мов називаємо їх хибнимилексичними паралелями, що в описаному словнику позначаємо знаком $\Lambda$.

Напр.,

\begin{tabular}{|c|c|}
\hline $\begin{array}{l}\text { А ГАЛЬМ/O, -а, ср: } \\
\text { 1. пристрій для сповільнення руху або } \\
\text { зупинки транспорту і т. ін.: застарілі } \\
\text { гальма, натиснути на гальмо } \\
\text { - Вremse; } \\
\text { 2. те, що затримує що-небудь, не } \\
\text { дає розвиватися, рухатися вперед; } \\
\text { перешкода, затримка: корупція - гальмо } \\
\text { економіки } \\
\text { - Вremse. }\end{array}$ & $\begin{array}{l}\text { А Наاm, m: } \\
\text { 1. стеблина, соломинка: die Halme } \\
\text { der Gräser sind geknickt; } \\
\text { 2. соломинка для напоїв: den Saft mit } \\
\text { einem Halm trinken. }\end{array}$ \\
\hline $\begin{array}{l}\text { А коХ/АТИ, -аю, -аєш, недок.: } \\
\text { 1. почувати, виявляти глибоку } \\
\text { сердечну прихильність до особи іншої } \\
\text { статі; любити } \\
\text { - gerne haben; lieben; } \\
\text { 2. дбайливо вирощувати, плекати } \\
\text { що-небудь, ходити коло чогось } \\
\text { - liebevoll pflegen. }\end{array}$ & $\begin{array}{l}\text { А kochen, v: } \\
\text { 1. готувати їу, варити: zum } \\
\text { Mittagessen eine Suppe kochen, das } \\
\text { Mittagessen kochen; } \\
\text { 2. варитися: Die Kartoffel kochen } \\
\text { schon } 20 \text { Minuten } \\
\text { 3. кипіти: Das Wasser kocht schon. }\end{array}$ \\
\hline
\end{tabular}

Зауважимо, що наведені приклади демонструють випадкові (етимологічно не пов'язані) збіжності зовнішніх форм лексичних одиниць української та німецької мов.

Основну частину словника складають неповні лексичні паралелі. Про такі ЛП говоримо в тому разі, коли деякі значення (семеми) зовнішньо схожих лексичних одиниць у двох чи більше мовах збігаються, а деякі - не збігаються.

Збіжні значення називаємо інтерсемемами, а незбіжні, що відображають національно-культурну своєрідність лексичної одиниці, - iдіосемемами. Інтерсемеми в словнику позначаються знаком = “дорівнюе”, а ідіосемеми - знаком * "зірочка". 
Напр.

\begin{tabular}{|c|c|}
\hline $\begin{array}{l}\text { РЕШТ/А, -и, ж: } \\
\text { 1. те, що залишилось } \\
\text { невикористаним, } \\
\text { незайнятим і т. ін.: викинути рештут; } \\
\text { 2*. те, що додається до чого-небудь, } \\
\text { доповнює щось: використати решту, } \\
\text { додати решту матеріалів } \\
\text { - Ergänzung, Zusatz; } \\
\text { 3. сума грошей, що повертається при } \\
\text { розрахункові; здача: отримати решту } \\
\text { від продавия. }\end{array}$ & 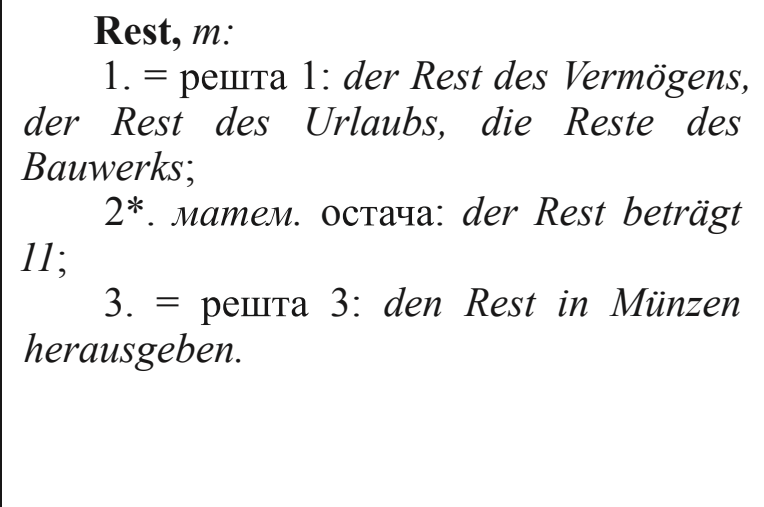 \\
\hline
\end{tabular}

Як бачимо з прикладу, семантичні структури укр. pewma та нім. Rest мають по три значення (по дві інтерсемеми та по одній ідіосемемі). Кожній українській ідіосемемі надаються німецькі перекладні еквіваленти.

Крім того, навіть у збіжних значеннях (інтерсемемах) можна виокремити дрібні значеннєві відмінності (ідіосеми - відмінні семи, що підкреслюють національно-культурну специфіку збіжних значень). У словнику їх позначено знаками > - звуження значення, або <- розширення значення.

Напр.,

\begin{tabular}{|c|c|}
\hline $\begin{array}{l}\text { БУДК/А, -и, ж: } \\
1 . \quad \text { невелика будівля для } \\
\text { господарських потреб, для захисту від } \\
\text { негоди та ін.: будка в садку } \\
\text { - а ткж Schuppen; } \\
\text { 2*. невеличке крите приміщення } \\
\text { для собаки; будка, конура: собача будка, } \\
\text { будка для тварин в зоопарку } \\
\text { - Нundehütte, Entenhütte. }\end{array}$ & $\begin{array}{l}\text { Bude, } f \text { : } \\
\text { 1.= будка } 1 \text { > ринковий намет, кіоск: } \\
\text { Würstelbude; } \\
\text { 2*. poзм. будинок у дуже поганому } \\
\text { стані: Was ist denn das für eine Bude?; } \\
\text { 3*. poзм. засm. квартира, кімната, } \\
\text { як правило, студентська: in der Bude } \\
\text { aufräumen. }\end{array}$ \\
\hline $\begin{array}{l}\text { КИЛИМ, -а, ч: } \\
\text { тканий, найчастіше ворсистий, } 3 \\
\text { візерунками виріб для вкривання підлоги, } \\
\text { оздоблювання стін тощо: турецький } \\
\text { килим, килим на стіні. }\end{array}$ & $\begin{array}{l}\text { Kelim, } m: \\
\quad=\text { килим }>\text { тільки східний, як правило, } \\
\text { ручної роботи: einen teuren Kelim kaufen }\end{array}$ \\
\hline $\begin{array}{l}\text { А ляд/А, -и, ж: } \\
\text { 1. рухома покришка, дверцята, що } \\
\text { прикривають отвір всередину чого- } \\
\text { небудь: відчинити ляду } \\
\text { - Кlappe, Türchen, Fensterchen; } \\
\text { 2. відкидна полиця або віконниця } \\
\text { в крамниці, що застосовується як } \\
\text { прилавок: торгівля з ляди } \\
\text { - Verkaufsfensterchen. }\end{array}$ & $\begin{array}{l}\text { A Lade, } f \text { : } \\
\text { шухляда: die Lade öffnen, Schublade; } \\
\text { Laden, } m \text { : } \\
1^{*} . \text { крамниця: im nächsten Laden } \\
\text { einkaufen; } \\
2 .=\text { ляда } 2<\text { прилавок, лоток: die } \\
\text { Waren auf dem Laden auflegen; } \\
3^{*} . \text { віконниці: die Laden schließen, } \\
\text { Fensterladen. }\end{array}$ \\
\hline
\end{tabular}


ОЛІ/Я, -ї, ж:

1. рідка жирова речовина, яку добувають 3 деяких рослин (переважно 3 їхнього насіння або плодів): гарбузова олія, соняшникова олія;

2. фарба з цієї речовини: червона олія

- a ткж Ölfarbe
Öl, $n$ :

1. = олія $1<$ а ткж вершкова, машинна тощо речовина: in Öl herausbacken, Essig und Öl für den Salat; das Auto verliert Öl ;

2*. нафта: nach Öl bohren, Erdöl;

$3^{*}$. паливо з нафти: mit Öl heizen, Heizöl;

4. = олія 2: ein Gemälde in Öl und Tempera; Ölgemälde.

Повними лексичними паралелями називаємо зовнішньо схожі слова двох чи декількох синхронічно порівнюваних мов з повністю збіжними значеннями або 3 певними нюансами стилістичного, граматичного тощо характеру та розширенням / звуженням збіжних значень.

Напр.,

ДАХ, -у, ч:

1. верхня частина будівлі, що служить iї покриттям; покрівля: даx будинку;

2. помешкання: мати дах над головою;

3. підтримка, сприяння: працювати під дахом комериійних структур.
МАЛЯР, -а, ч:

1. робітник, який займається фарбуванням будов, стін приміщень: бригада малярів

- а ткж Anstreicher;

2. живописець, художник, митець, що займається живописом, малярством: визнаний маляр.

\section{Dach, $n$ :}

1.= дах 1: das Dach des Hauses, auf das Dach steigen, das Dach ist undicht;

2. = дах 2: ein Dach über dem Kopf haben, unter einem fremden Dach wohnen;

3. = дах 3: sich unter das Dach einer politischen Partei begeben.

Зазначимо, що у WDLP у польського слова malarz виокремлюється ще третє значення 'człowiek umiejący obrazowo opisywać lub opowiadać', яке відсутнє як у німецькій, так і в українській мовах.

ПАПІР, паперу, ч:

1. матеріал для писання, друку, малювання i т. ін., виготовлений 3 ганчіркової, деревної та іншої маси: папір для друку, іграшка з паперу;

2. письмовий документ офіційного характеру: підписати папip.
Maler, $m$ :

1. = маляр 2: den Maler zum Ausmalen kommen lassen;

2. = маляр 1: die Maler der Renaissance.

\begin{tabular}{|c|c|}
\hline $\begin{array}{l}\text { ПАПІР, паперу, ч: } \\
\text { 1. матеріал для писання, друку, } \\
\text { малювання і т. ін., виготовлений } 3 \\
\text { ганчіркової, деревної та іншої маси: } \\
\text { папір для друку, іграшка з паперу; } \\
\text { 2. письмовий документ офіційного } \\
\text { характеру: підписати папір. }\end{array}$ & $\begin{array}{l}\text { Papier, } n \text { : } \\
\text { 1. = папір 1: auf Papier zeichnen, } \\
\text { Millimeterpapier, Papier in den Drucker } \\
\text { einlegen, Papier falten; Papierservietten; } \\
\text { 2. = папір 2: ein Papier für den } \\
\text { Vorsitzenden zusammenstellen; } \\
\text { 3. папір } 2>\text { mільки мн. документи- } \\
\text { посвідчення: Mir wurden alle Papiere } \\
\text { gestohlen. }\end{array}$ \\
\hline
\end{tabular}


Повні та неповні ЛП можна віднести до так званих інтернаціональних слів (лексичних інтернаціоналізмів), що їх визначаємо як зовнішньо схожі лексичні одиниці різних мов, у семантичній структурі яких збігається хоча б одне зі значень. Ступінь інтернаціональності лексичних інтернаціоналізмів тим вищий, чим у більшій кількості мов вони збігаються за значеннями.

Від традиційного для лінгвістики терміна "хибні друзі перекладача" ми відмовилися через його метафоричність (це вважається небажаним для термінологічної лексики), а також через те, що традиційно не проводиться відмінність між “хибними друзями”-словами та "хибними друзями"-значеннями. У запропонованій термінології їх, відповідно, називаємо хибними ЛП й ідіосемемами.

Схематично різновиди лексичних паралелей можна зобразити так:

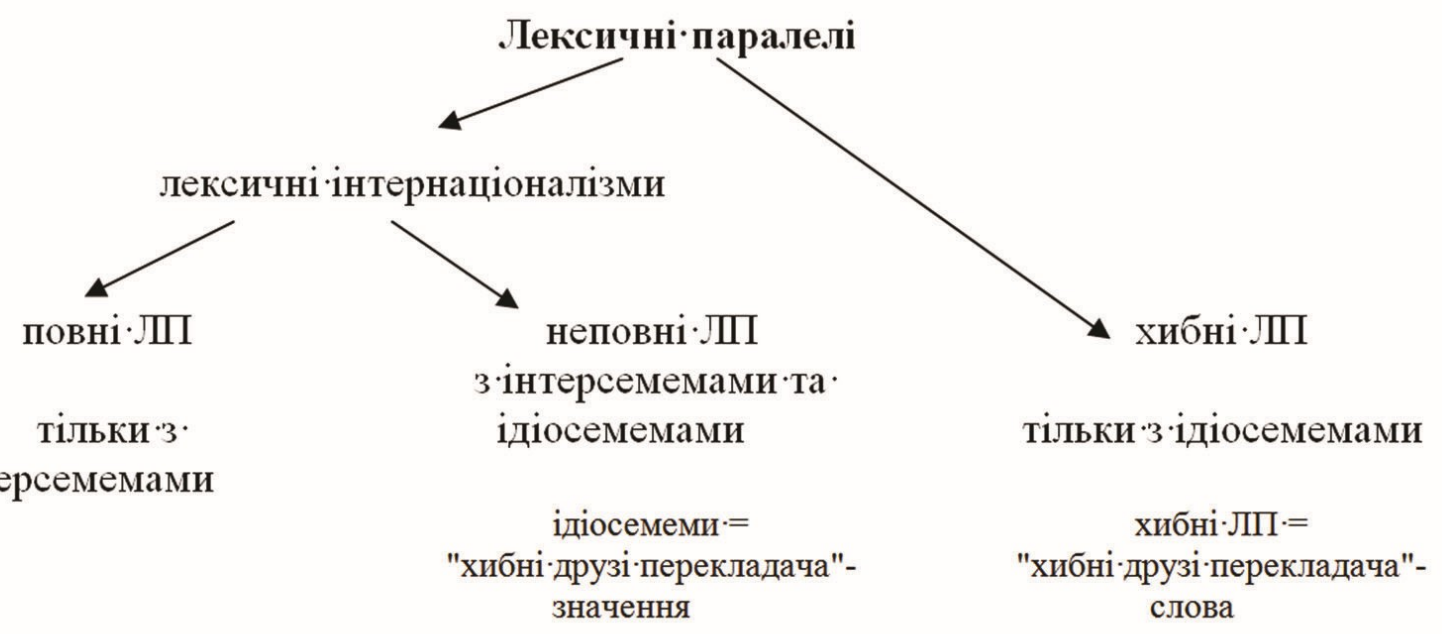

Інше значення вкладаємо в поняття міжмовні омоніми та міжмовні пароніми.

Виходячи 3 принципового положення про те, що омонімія - внутрішньомовна лексико-семантична категорія (омоніми виділяються лише в межах однієї мови), під міжмовною омонімією розуміємо зовнішньо (фонетично / графічно) та семантично схожі паралельні опозиції двох синхронічно порівнюваних мов, тобто щонайменше чотиричленну структуру, коли схожість омонімів (по два в кожній мові) спостерігаємо в різних мовах. Напр., в українській та німецькій мовах:

\section{ПАСУВАТИ I:}

1.чимось подобатися, годитися, відповідати кому-, чому-небудь, личити: тобі пасує ия сукня;

2. бути зручним, прийнятним для кого-, чого-небудь: його прачя пасує ціий cumyauiii.

\section{ПАСУВАТИ ІІ:}

1. у спортивній грі 3 м'ячем передавати м'яча: пасувати м'яча захисникові своєї команди;

2. у карточній грі - відмовлятися від участі в розіграші або кидати гру (до наступного розіграшу): пропускаю ией хід - я пас (ую).

\section{passen I:}

1. = пасувати I, 1: Dieses Kleid passt mir (за кольором, розміром);

2. розм. = пасувати I, 2: Passt Dir dieser Vorschlag?

\section{passen II:}

1. = пасувати II, 1: den Ball an einen Mitspieler passen;

2. = пасувати II, 2: Ich passe! 
Міжмовна омонімія передбачає порівняння омонімічних (у кожній із зіставлюваних мов) повних, неповних і хибних лексичних паралелей. Як бачимо 3 наведеного прикладу, міжмовними омонімами є два омоніми української мови пасувати I / пасувати II і два омоніми німецької мови passen I / passen II.

При цьому лексичними паралелями двох мов $\epsilon$ (у цьому разі чотири пари ЛП — чотиричленна омонімічна структура): укр. пасувати I/ нiм. passen I, yкр. пасувати I / нiм. passen II, укр. пасувати II / нiм. passen I, укр. пасувати II / нiм. passen II.

Міжмовними паронімами називаємо лише такі лексичні паралелі, які в кожній із щонайменше двох зіставлюваних мов можуть викликати хибні асоціації, ототожнюватися одна $з$ іншою в разі незбіжності їхніх значень. Виходячи з того, що паронімія, як і омонімія, - внутрішньомовна лексико-семантична категорія, міжмовну паронімію можемо спостерігати лише за умови порівняння двох (трьох, чотирьох і більше) паронімів однієї мови з двома (трьома, чотирма та більше) паронімами іншої мови.

Напр.,

\section{генеральний генеральський}

ГЕНЕРАЛЬН/Й̆, -а, -е:

\section{General- \\ Generals- generell}

General- (у складі складного слова):

1. = генеральний 1 ;

2. = генеральний 2;

3. = генеральний 3 .

2. загальний: генеральна асамблея;

3. головний, керівний (про Generals- (у складі складного слова): посаду): генеральний конструктор, = генеральський.

генеральний директор.

ГЕНЕРАЛЬСЬК/Й̆, -а, -е:

той, що стосується генерала; загальний, без деталей: eine generelle такий, як у генерала: генеральський Annahme treffen. мундир.

Як бачимо 3 наведеного прикладу, міжмовна паронімія виникає під час порівняння двох паронімів української мови генеральний // генеральський з трьома паронімами німецької мови General-// Generals- // generell.

При цьому відповідні у двох мовах пари генеральний-General-, генеральний-Generals-, генеральний-generell, генеральський-General-, генеральський - Generals-, генеральський-generell є лексичними паралелями.

Крім того, спостерігаємо новий феномен - міжмовну омонімо-паронімію (паронімо-омонімію), тобто змішування міжмовних опозицій омонімів однієї мови із зовнішньо схожими паронімами іншої мови та, навпаки, - паронімів однієї мови із зовнішньо схожими омонімами іншої мови. Наведемо відповідні приклади. 
Міжмовна омонімо-паронімія:

\begin{tabular}{|c|c|}
\hline $\begin{array}{l}\text { KОМ/А I, -и, ж: } \\
\text { грам. розділовий знак, що має форму } \\
\text { гачка (,); уживається для відокремлення } \\
\text { слів, словосполук і речень: кома } \\
\text { посередині тексту } \\
\text { - а ткж австр. Beistrich; } \\
\text { КОМ/А II, -и, ж: } \\
\text { мед. стан організму, що } \\
\text { характеризується втратою свідомості } \\
\text { з порушенням чутливості, розладом } \\
\text { життєво важливих функцій- кровообігу } \\
\text { й дихання: впасти в кому. }\end{array}$ & $\begin{array}{l}\text { Komma, } n: \\
=\text { кома I: ein Komma setzen. }\end{array}$ \\
\hline
\end{tabular}

Простежуємо міжмовну опозицію двох українських омонімів кома I / кома II з двома зовнішньо схожими німецькими паронімами Komma / Koma (чотиричленна структура).

Міжмовна паронімо-омонімія:

\begin{tabular}{|c|c|}
\hline $\begin{array}{l}\text { КО́ШТ/УВАТИ, -ую, -уєш, рідко: } \\
\text { 1. мати вартість у грошовому } \\
\text { вираженні: скільки ко́штує ия книга?; } \\
\text { 2. вимагати певних зусиль, витрат } \\
\text { для свого здійснення: справа ко́штує } \\
\text { зусиль всіх організашій. } \\
\text { КОШТ/УВА́ТИ, -у́ю, -у́єш, недок.: } \\
\text { спробувати якусь їжу, напої: } \\
\text { скоштува́ти м'ясо } \\
\text { - а ткж рrobieren. }\end{array}$ & $\begin{array}{l}\text { kosten I, v: } \\
\text { 1. = ко́штувати 1: Die Zeitung kostet } \\
\text { einen Euro; } \\
\text { 2. = ко́штувати 2: Die Verhandlungen } \\
\text { haben viel Zeit und Kraft gekostet. } \\
\quad \text { kosten II, } v \text { : } \\
\quad=\text { коштува́ти: Kosten Sie unsere } \\
\text { Suppen und Desserts! }\end{array}$ \\
\hline
\end{tabular}

Спостерігаємо міжмовну опозицію двох українських паронімів ко́штувати / коштува́ти 3 двома зовнішньо схожими німецькими омонімами kosten I / kosten II (чотиричленна структура).

Отже, згідно з теорією лексичних паралелей, підсумуємо визначення запропонованих термінів: 1) зовнішньо схожі лексичні одинииі двох синхронічно порівнюваних української та німецької мов - це кореляти, що збігаються до ступеня ототожнення за усною та письмовою формою, включаючи закономірні відповідники звуків і літер кирилиці та латини; 2) лексична паралель зовнішньо схожі кореляти двох синхронічно порівнюваних мов; залежно від збіжності / неповної збіжності / незбіжності семантичних обсягів та / або окремих значень порівнюваних слів лексичні паралелі бувають повними ЛП, неповними ЛП та хибними ЛП; 3) “хибні друзі перекладача"-слова 3 повним набором незбіжних значень вважаємо хибними лексичними паралелями; "хибні друзі перекладача"-значення, за поданою теоретичною концепцією, — це idioceмeми; 4) лексичні інтернаціоналізми - зовнішньо схожі лексичні одиниці щонайменше двох синхронічно порівнюваних мов, у семантичній структурі яких збігається хоча б одне зі значень (є хоча б одна інтерсемема); а отже, лексичними інтернаціоналізмами вважаємо повні та неповні лексичні паралелі; 5) міжмовні омоніми, згідно з теорією лексичних паралелей, — це зовнішньо схожі одиниці за умови зіставлення двох чи більше омонімів однієї мови з двома чи більше омонімами іншої мови; аналогічно, міжмовними паронімами є паралельні опозиції паронімів двох порівнюваних мов. 
Запропонована в словнику процедура лексикографічного дослідження лексичних паралелей - відкрита система. Вона найбільш адекватно репрезентує лексичні паралелі в порівнюваних мовах, показує їхню формально-змістову близькість i національно-культурну своєрідність, передбачає перекладацькі труднощі, акцентує на можливих інтерференційних помилках.

\section{Список використаної літератури}

Дубічинський В., Ройтер Т., Теоретичні та практичні засади лексикографічного опису українсько-німецьких лексичних паралелей, [в:] Украӥнська і слов'янська тлумачна та перекладна лексикографія, відп. ред. І. С. Гнатюк, Київ 2012, с. 114-119.

Дубичинский В. В., Ройтер Т., Теория и лексикографическое описание лексических параллелей, моногр., Харьков 2015.

Дубичинский В., Ройтер Т., Уточнения к определению лексических параллелей, [в:] „Vоcabulum et vocabularium", Минск 2017, вып. 15, с. 353-358.

Besters-Dilger J., Deutsche lexikalische Entlehnungen im Ukrainischen. Zur Frage der polnischen Vermittlung und heutigen Aktualität, [in:] Litteraria humanitas XI: Crossroads of Cultures: Central Europe, red. I. Pospíšil, Brno 2002, s. 25-51.

Dubichynskyi V., Reuther T., Lexical parallels: definitions, types, examples (Russian, German, English, Spanish), [в:] Cмыслы, тексты и другие захватывающие сюжеты, сб. статей в честь 80-летия И. А. Мельчука, Москва 2012, с. 124-134.

Filatova N., Ukrainisch im Kontakt mit anderen europäischen Sprachen. Englische, deutsche, russische Entlehnungen im Bereich der Politik, Erlangen 2007.

WDLP $=$ Wörterbuch der deutschen Lehnwörter in der polnischen Schrift- und Standardsprache. Von den Anfängendes polnischen Schrifttums bis in die Mitte des 20. Jahrhunderts. Hgg. Andrzej de Vincenz, Gerd Hentschel, Oldenburg 2010 (=Studia Slavica Oldenburgensia 20), [in:] Elektronische Ressource: http://diglib.bis.uni-oldenburg.de/ bis-verlag/wdlp/ab_A.html.

\section{Spysok vykorystanoi literatury [References]}

Dubichinskij V., Rojter T., Teoretychni ta praktychni zasady leksykohrafichnoho opysu ukrainskonimetskykh leksychnykh paralelei [Theoretical and Practical Fundamentals of Lexicographic Description of Ukrainian-German Lexical Parallels], [v:] Ukrainska i slovianska tlumachna ta perekladna leksykohrafiia, vidp. red. I. S. Hnatiuk, Kyiv 2012, s. 114-119.

Dubichinskij V. V., Rojter T., Teoriya i leksikograficheskoe opisanie leksicheskih parallelej [Theory and Lexicographic Description of Lexical Parallels], monogr., Har'kov 2015.

Dubichinskij V., Rojter T., Utochneniya $k$ opredeleniyu leksicheskih parallelej [Elimination on Lexical Parallels Definition], [v:] „Vocabulum et vocabularium”, Mynsk 2017, vip. 15, s. 353-358.

Besters-Dilger J., Deutsche lexikalische Entlehnungen im Ukrainischen. Zur Frage der polnischen Vermittlung und heutigen Aktualität [in:] Litteraria humanitas XI: Crossroads of Cultures: Central Europe, red. I. Pospíšil, Brno 2002, s. 25-51.

Dubichynskyi V., Reuther T., Lexical parallels: definitions, types, examples (Russian, German, English, Spanish), [v:] Smisli, teksti y druhye zakhvativaiushchye siuzheti, sb. statei v chest 80-letyia Y. A. Melchuka, Moskva 2012, s. 124-134.

Filatova N., Ukrainisch im Kontakt mit anderen europäischen Sprachen. Englische, deutsche, russische Entlehnungen im Bereich der Politik, Erlangen 2007.

WDLP = Wörterbuch der deutschen Lehnwörter in der polnischen Schrift- und Standardsprache. Von den Anfängendes polnischen Schrifttums bis in die Mitte des 20. Jahrhunderts. Hgg. Andrzej de Vincenz, Gerd Hentschel, Oldenburg 2010 (=Studia Slavica Oldenburgensia 20), [in:] Elektronische Ressource: http://diglib.bis.unioldenburg.de/bis-verlag/wdlp/ab_A.html. 